\title{
Study on the Discourse Power of Government in Public Opinion
}

\author{
Lei Lei \\ College of Marxisma \\ Wuhan University of Science and Technology \\ Wuhan, China
}

\begin{abstract}
Public opinion is the main characterization to reflect social issue and public voice. We should master the negative influence caused by public opinion through analyzing and knowing about it. This paper discusses the relationship among feature of public opinion, hot public opinion and discourse power. Based on the analysis of public opinion on Internet recently, we can find the discourse power of government in public opinion and the approach to increase the power. Hopefully it can give some help to the service-oriented government on its developing way.
\end{abstract}

Keywords-public opinion; discourse power; discourse power of government

\section{INTRODUCTION}

Public opinion is total of belief, attitude, suggestions and emotion react to incidents, phenomenon and problems in real society during a special period. It seems a reaction based on public's thought and mentality. While public political attitude becomes the common idea, public opinion is close to public voice. The concept of public opinion is not new. It is significant on the way of society developing.

\section{FEATURE OF PUBLIC OPINION}

The way of self-expression has changed a lot in the Internet era. With the bloom of mew media, public opinion shows out new features.

First of all, it is virtuality. The rate of Internet penetration is raising year by year, form $31.8 \%$ in 2012 to $50.3 \%$ in 2016 , consisting 688 million enormous cyber group in China. All of those make Internet being the most important carrier of public opinion. People can anonymously publish articles. On the meantime, they receive the same messages. A large amount of messages are being sent and received every day. It is hard to tell the truth of them in the Internet. Those all prove that virtuality is a significant feature of public opinion. This feature can cause some negative influence, for example spreading rumors and network crime.

Secondly, it is globalization. With the fast development of economy and popularization of Internet, people will not only focus on domestic and they no longer believe that everything is better in overseas. Internet connects every remote hemisphere to be a whole, so that long and arduous journey can't hinder spread of messages. Globalization is a new feature in the Internet era. We can find some social problems in overseas except domestic, for example Libya's political situation and Snowdon prism door event those which are one of hot public opinion event in 2011 and 2013. All of those undoubtedly to show its feature of globalization.

Thirdly it is interactivity. Before the Internet era, the way of spread public opinion is single-track. Media publish the opinion, which including their own ideas, to ordinary people. People only can read them. However in the Internet era, people can get many first-hand messages through Microblog, Post bar and Forum. They can commend the messages to show their attitude. Ordinary people actively take part in the public opinion from the positively. So from this era, both media and ordinary take part in the spread public opinion, not the single-track any more. For example, mass media let people to comment. People can comment and read others' comments. They can exchange ideas with media to achieve the interaction of both sides.

Finally it is explosive. Internet has the feature of instantaneity. Once an affair happened, it can spread out immediately in the Internet. It is hard to inspect the messages before and control after. On the one hand, instantaneity is convenient. On the other hand, it sometimes makes some trouble. Public opinion suddenly rising up will cause a big response both in real life and Internet. This feature appears with the beginning of Internet era.

\section{RELATIONSHIP OF HOT PUBLIC OPINION AND DISCOURSE POWER}

\section{A. Government Discourse power Is Influenced by Ratio of Positive and Negative in the Public Opinion Event.}

All hot public opinion events considered each year, it is easy to find, government's credibility will be cut down while huge positive influence causing by negative public opinion. Besides, it will be a big attack on government disclosure power. In 2010, the top 20 hot public opinion events, like "Li's son hit man to death in at the campus", "selfimmolation in Yihuang", "insecurity vaccine in Shanxi", "Zhao Zuohai's unjust case in Shangqiu", arose public dissatisfaction of the officer offspring's arrogance, violence law enforcement, endangering livelihood, judicial injustice and so on. All of these make people turns to write their dissatisfaction on Internet in 2010. At that time, a number of 
"group" guide the direction. The group publish some trenchant words to get attract. After gotten large followers, their words and deeds will have a huge impact, especially the attitude on some social problems. Once the group has different ideas with government and $\mathrm{CCP}$, basing on some negative affairs on net, people easier to believe and agree with the group. It will deeply reduce the status of government discourse power. However new government starts to renovation on net in 2013. Not only the meeting about National Propaganda Thought on August, but also the law some explanation on Internet information security, have play a big role on management of public opinion. At the same year, top one "Xue's detention due to whoring" has changed some people's belief of the group. So among the top 20 hot affairs in 2013, negative affairs reduce. Governmental discourse power is improved a lot. Overcoming the difficulty of reform in 2014, the central government made intensity anti-corruption which helps improve the people's centripetal power. Between the government departments and the group, people no longer blindly follow the group's point of view. They objectively look on the government department's analysis and their present facts. At this case, people's understanding and trust of government and party has increased. According party and government's status of discourse power is improved.

\section{B. Attention of Affairs Reflect Each of People Expressing Their Own D iscourse Power}

The public opinion monitoring room of People's Network will release the hot events in its public opinion analysis report of Chinese Internet every year. Almost all of those come from micro blog and other websites. For example the dates are from Tianlang Community, Kaidi Community, Qiangguo Forum, Xinlang Forum, Zhonghuawang Forum, Xinlang Blog in 2010. The big part is the main posts and comments in every community according to statistics. The active involvement of people obviously expresses their own discourse power. Hot affairs in 2010 are mainly about protection of civil rights, public power supervision, public order maintenance, promoting public morality and so on such series of social problems; Hot affairs in 2011 are about security of public traffic, loss of public morality, public health security and so on; Hot affairs in 2012 are also highlight people livelihood issues and problems on government public management; Hot affairs in 2013 are still about livelihood issues and personal right protection. Top one hot affairs in 2014 is lost of Malaysian Airline, others are some complain about violent and terrorist attacks; The hot affairs in 2015 are not mainly about livelihood issues, instead are sports entertainment, public figures and military diplomacy. From the distribution of every year hot affairs, people are more concerned about social problems and livelihood at first. People comment on the Internet is the best way that government getting advice, not useless. Party and government obtain the comments of hot affairs in order to protect public discourse power. They can know which parts are people concerned, where are the problems and how to improve. For example, party and government reinforce management, enforce the law and safeguard the civil basic right to improving security of society; they optimize social protection system, strengthen health care system to solve livelihood issues. Besides, hot opinions issues are more rational and internationalized, not all focusing on livelihood and some unfair issues with government paying much attention to the comments. As for some untruth rumor in the Internet, especially "democracy and freedom" which disturbs people feeling, we should expose them without hesitation.

\section{The One Who Has the Advantage of Discourse Power Always Can Lead the Hot Events.}

We have mentioned before that the Public opinion is total of belief, attitude, suggestions and emotion react to incidents, phenomenon and problems in real society during a special period. However it is easy to change and easily be affected by external environment. Typically is the top one hot affair in 2010, Diaoyu Islands and demonstration of object to Japan. At the beginning, people have the same thinking that is Diaoyu Island belongs to China. We object to any form of disturb China's sovereignty and territorial integrity. However under the instigation, people are doing the crazy things. They organize demonstration and even smash goods which are made in Japan and shops which are selling Japanese products. They seem patriotic actually destroying other innocent citizen's belongings. All of those show that, in the Internet era, the one who has advantage of discourse power can lead the hot affairs. In recently years, under the leadership of president $\mathrm{Xi}$, government strengthens the governing capacity, pushes forward reform and strengthens ideological publicity. All of these changes are in order to promote trust between government and people. Government start official accounts in Internet platform, such as the account in Micro-blog to follow the fashion. These will promote trust of government.

\section{HOW TO STRENGTHEN GOVERNMENT DisCOURSE POWER IN INTERNET?}

\section{A. Promote the Trust on Government}

Internet public opinion arising have many reasons. One of the important roles is government. In order to win the discourse power and lead the affairs, people have to increase faith in the government. Form the top hot affairs in the ranking list, we can know that government really affect the results. After the $18^{\text {th }}$, party and government make deeply reform, strengthen law-based governance policy, strengthen party self-discipline and seriously dispose corruption. So after that, hot affairs about law enforcement dispute, patienthospital dispute, guilty of corruption and accepting bribes are decrease. From "fire event causing by pulling down house in Yihuang" in 2010 to "premier Li delegating right to lower levels" in 2015, the changes show that people starts to trust government. The trust helps the control of hot affairs and leads the public to truth. Socialism constriction is on the way, so governmental construction can't stop. The promotion of trust on government helps the firm improvement of its discourse power and the public opinion guidance to the right way. 


\section{B. To Make Systematic Strategy of Media Management}

Media is public implement. It has the duty to supervise and expose the bad side of society. Because of that, it gains high reliability and infection. People's daily on behalf of party's spokesman helps public know government the newest developing direction. It is found by party means that it has to fellow party's leadership, safeguards party's power and maintains party's unity said by President Xi on the new and hot affairs meeting. He wants people's daily and party to be consistent and feedback public's voice in time. However in the Internet era, paper media has to face a lot crisis and reinforce management, not being weed out, with app media occupying large of market. So government should complete media management to keep balance and healthy of media market. If not, it will lose the initiative of leadership in hot affairs and discourse power, finally losing its prestige. People's daily belongs to party's media. We should protect its market position to hear the voice from party and public. In facing some problems, people's daily should know people's feedback and give correct comments of leadership. Because of people's daily reacts party, it has to tell truth, leads the right direction and finishes the party's work about new and hot affairs. How can people's daily on behalf of party ignore the discourse power of government? So it is very important to establish systematic and scientific media management policy.

After the reform and opening-up policy, our country are facing many problems, including some people can't adapt the changes of market-oriented economy's fast pace. This problem can cause many negative influences. It will turn to dissatisfaction of government and increase government's pressure. With the deeply reform, more and more problems come out. The conflict of interest causes social contradiction. In this case, government turns to service-oriented and brings many chances and challenge. Service-oriented government more focuses on people and gives right to people. At the meantime, we can't lose the leadership of hot affairs and government discourse power. We promote the trust on government and complete management policy. After that, the most important is that we should have comprehensive attitude to public opinion. Comprehensive attitude help heard much more voice from public people. But premise is the government protection. It can block fake information to disturb people, help people know the truth and reduce social disruption. Our comprehensive is to the people who has confusion, dissatisfaction and treat-unjustly can have the right place to get back. All of our good points are to the people, not the rumor mongers who hurt government and others. We should strongly resist rumor. Before transformation of government, we always heard the report that someone is restricted for personal freedom because of petition, and house was force to be pulled down. However before these report, we never heard the voice from victim. After report, all the bad points to government. During these years, with the popularity of Internet, more and more voice from victims can be heard. And government is not using crude way to solve it any more. Powerful clarification of rumor and tell out truth in timely will not give chance of conspiracy theorists to destroy stability. Comprehensive attitude to public opinion is indispensable for stable leadership of government discourse power. So we have to pay attention to people's real voice. Get known the truth before public opinion event happens, make analyze in time and finally solve it.

\section{CONCLUSION}

Public opinion needs be concerned but more the right direction guidance. We should learn how to analysis and solve the public opinion. It is the good feedback to improve social management and strengthen social construction. Only the way of improving government discourse power can reply to hot affairs crisis and the bad group guidance. Government should take care of the chances and challenge in the Internet era, pay much attention to public feelings coming from affairs and increase knowledge and experience on solving the problems. We should firmly hold the government discourse power in Internet, maximal avoid and reduce negative influence. Harmonious socialist society is on the way.

\section{REFERENCES}

[1] Peng Weibu/ chief editor. Public Opinion Research on Hot events 2. Beijing: Economic Daily Press. 2014 edition.

[2] Netease News Center. Remember that "the party's media must serve the party" http://news.163.com/16/0226/04/BGNME5LJ00014AEF.html(2016/7 /16).

[3] Hao Feng. The construction path of the ideological discourse power of the ruling party under the "Micro-era $[\mathrm{J}]$. Knowledge and Behavior, November 2015, No. 4.

[4] Public Opinion Monitoring Room of People's Network. public opinion analysis report of China Internet (2011 - 2015) [R]. People's Network, 2011 - 2015

[5] Bi Yiming. To Create the Public Opinion Field of Gathering Positive Energy - The New Ideas Guided by Public Opinion [N]. China Broadcasting, 2013-07-15. 